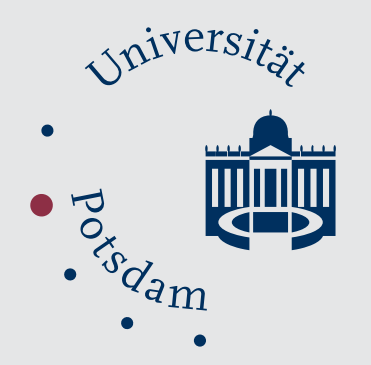

\title{
Philosophische Fakultät
}

Lars Eckstein

Sam Selvon, The Lonely Londoners (1956)

Preprint published at the Institutional Repository of the Potsdam University: http://nbn-resolving.de/urn:nbn:de:kobv:517-opus4-103285 

Sam Selvon, The Lonely Londoners (1956) 

Lars Eckstein

Sam Selvon, The Lonely Londoners (1956) 
University of Potsdam 2017

Published online at the

Institutional Repository of the University of Potsdam:

URN urn:nbn:de:kobv:517-opus4-103285

http://nbn-resolving.de/urn:nbn:de:kobv:517-opus4-103285 
Lars Eckstein

\title{
13 Sam Selvon, The Lonely Londoners (1956)
}

\begin{abstract}
This essay reads Sam Selvon's novel The Lonely Londoners (1956) as a milestone in the decolonisation of British fiction. After an introduction to Selvon and the core composition of the novel, it discusses the ways in which the narrative takes on issues of race and racism, how it in the tradition of the Trinidadian carnival confronts audiences with sexual profanation and black masculine swagger, and not least how the novel, especially through its elaborate use of creole Englishes, reimagines London as a West Indian metropolis. The essay then turns more systematically to the ways in which Selvon translates Western literary models and their isolated subject positions into collective modes of narrative performance taken from Caribbean orature and the calypsonian tradition. The Lonely Londoners breathes entirely new life into the ossified conventions of the English novel, and imbues it with unforeseen aesthetic, ethical, political and epistemological possibilities.
\end{abstract}

Key Words: 1948 Nationality Act - racism - kiff-kiff laughter - creolisation - calypso

\section{Context: Author, Oeuvre, Moment}

Sam Selvon's The Lonely Londoners marks a milestone in the decolonisation of the British novelistic tradition. It not only puts Black Britons indelibly on the map of the heart of Empire in what critics have termed a "colonisation in reverse" (Ramchand 2001, 7; cf. Dawson 2007). It also infuses Anglophone fiction with unprecedented aesthetic and epistemic innovations, as one of the first English novels entirely written in a literary creole, and as a novel which effectively translates the ossified European conventions of realism and modernism into distinctly Caribbean worldings. It riffs on the earlier Londoners of Dickens, Woolf or Eliot (Looker 1996, 75); yet its antiphonic and collective narrative form, its tragic-comic spirit, its carnivalesque humour and profanations, and not least its decolonial politics are inspired by Caribbean orature and the Calypsonian tradition. The empathetic humanity of its characters, its inspired critique of racist and social injustice, its profound epistemic negotiations and creolisations still outshine the work of later Black and Asian British writers such as Salman Rushdie ( 720 Salman Rushdie, The Satanic Verses (1988)) or Zadie Smith ( $\pi 25$ Zadie Smith, White Teeth (2000)) which were received with much more critical enthusiasm.

Samuel Dickson Selvon was born in San Fernando in the South of Trinidad in 1923 as one of seven children. His mother was of Indian and Scottish descent, his father, a dry-goods merchant, a first generation Christian immigrant from Madras. His 
parents could not afford Selvon's education beyond high school, and he left Naparima College in San Fernando at the age of 15. His first experiments in writing began during World War II, during the long hours of a job as a wireless operator in a local branch of the Royal Naval Reserve. After the war he moved to Port of Spain, did editorial work for the Trinidad Guardian, and began to publish short stories and poems, several of which were aired on BBC's Caribbean Voices, a London-based radio programme for Caribbean audiences originally installed to connect West Indian soldiers with their families back home. In its transformations after the war, the programme became formative for a whole generation of young Caribbean writers including George Lamming, Kamau Brathwaite, Derek Walcott, Andrew Salkey, V. S. Naipaul and many others, if not without controversy over the invasive editorial policies of its later Anglo-Irish producer, Henry Swanzy (Gramaglia and McIntosh 2013).

In April 1950, Sam Selvon emigrated to London, famously on the same boat as Barbadian writer George Lamming, whose second novel The Emigrants (1954) in many ways forms a companion piece to The Lonely Londoners. Like Lamming's In the Castle of my Skin (1953), Selvon's first novel A Brighter Sun (1952), most parts of which were still drafted in Trinidad, is a Bildungsroman set in the Caribbean. It chronicles the first five years of marriage of its protagonist, Tiger, to his arranged bride, Urmilla, which metonymically resonate with both local changes in the community and the larger economic and political transformations of the colony. Only with his third novel, The Lonely Londoners, did Selvon fully turn to his new home in England, where he initially found work as a clerk at the Indian embassy. His first residence was the Balmoral Hotel in South Kensington, a place which provided accommodation for students from the colonies as well as recent emigrants, and 'liming' with the other West Indians and Africans there provided him with the raw material for the motely cast of characters in The Lonely Londoners: "It was my first experience of living among other West Indian islanders, happening in the heart of London thousands of miles from home territory, and I learned as much about them as I learned about the English, whose ignorance of black people shocked me" (Selvon 1995, 58-59). Like the main focalising character of his novel, Moses Aloetta, Selvon found himself at the gravitational centre of a transient, and overwhelmingly male community of first wave colonial migrants who shared their 'ballad' of struggle and conquest in the capital of a nation that was both theirs, by right of the 1948 Nationality Act, and not theirs, by the diverse lived experiences they made.

The historical moment of The Lonely Londoners marks a decisive period in Britain's imperial past and postcolonial future. Published in 1956, the novel looks back on the first years of mass migration from the colonies since the arrival of the first group of 492 immigrants from the West Indies landing on 22 June 1948 at Tilbury on the MV Empire Windrush, the ship which came to provide the name for an entire generation. It is important to note that the waves of post-World War II migration were 
not the first to establish a substantial black presence in Britain, a presence which goes back as far as to the times of the Romans. In the late eighteenth century, following the American Revolution and the 1772 Somerset Case which effectively declared slavery illegal on English territory, the black population of London alone had peaked at an estimated 15,000 before it rapidly declined again in the nineteenth century (cf. Winder 2004; Fryer 1987). The Windrush generation resonates with these earlier generations of migrants, and Selvon's literature with that of earlier writings, be they Queen Elizabeth's 1601 proclamation against "the great number of Negroes and blackamoors which (as she is informed) are carried into this realm", issuing that "the said kind of people shall be with all speed avoided and discharged out of this her majesty's realms" (Burton and Loomba 2007, 158), or Olaudah Equiano's Interesting Narrative (1789) marking the beginnings of a black British literary tradition. Selvon's black Londoners were hardly the first, but they were the first to stay on a mass scale, and to lastingly transform the ethnic fabric of England.

Even though The Lonely Londoners focuses on the local struggles of colonial migrants in London and thus on a distinctly limited geographic setting, it is really embedded in the much larger politics of post-War reconstruction and, not least, the demise of the British Empire. The 1948 Nationality Act passed by the Attlee government, which established a new definition of UK citizenship that also included all residents of Empire born in the colonies, needs to be understood in the complex interplay of these contexts. Ashley Dawson (2007) elaborates that the Act's primary interest was indeed not in the creation of legal equity among all subjects of Empire, and least of all in the encouragement of migration to the motherland, but that it was much rather motivated by the 'loss' of India in August 1947. As such, the Act mainly served as "a powerful symbolic reaffirmation of the imperial system" in order to "defuse anticolonial nationalist movements" (Dawson 2007, 10). The Attlee government never lobbied for colonial migrants to rebuild the country, but instead actively recruited continental Europeans - white foreigners rather than black nationals - to settle in the UK; it really wished to forge a system where "imperial subjects were to be formally equal but geographically separate" (Dawson 2007, 10). It is hardly surprising, then, that the Windrush generation neither encountered the equality nor the hospitality they associated with the Nationality Act in their everyday experiences in the metropolitan heart of Empire. What they mostly found was systemic discrimination, most dramatically so on the housing and job markets, and aggravated by the institutional racism of political parties, agencies, trade unions and especially the metropolitan police. The lonely Londoners in Selvon's fiction are caught up in a system of classed and racial segregation at an historical moment when the inbuilt schizophrenia of Empire - the desire to remake the globe in one's own image, yet without surrendering the privilege of difference - hit home, quite literally, with a vengeance. 
Sam Selvon's work never ceased to engage with the alienations of migration, the trials of everyday survival, and the larger ironies of Empire, in various narrative modes ranging from sober realism to exuberant satire, from standard to creole Englishes, and shifting settings across the Atlantic. He in part built on the success of his first novels: Turn Again Tiger (1958), a sequel to A Brighter Sun (1952), traces Tiger's return to the world of his childhood. With Moses Ascending (1975) and Moses Migrating (1983), he extended The Lonely Londoners into a trilogy, following the life and aspirations of Moses Aloetta across the 1960s and 1970s. Some of Selvon's most inspiring further novels are I Hear Thunder (1962), The Housing Lark (1965), or The Plains of Caroni (1970). Yet he also continued radio work and collaborated on screen plays, most notably with Horace Ové for the formative classic of black British cinema, Pressure (1976). Selvon turned his back on England in 1978 and settled in Calgary, Canada. He died of lung disease on a return visit to Trinidad in 1994.

\section{Basic Coordinates: Central Topics and Concerns}

\subsection{Characters and Episodes}

The Lonely Londoners does not follow a conventional plot or narrative structure. Instead, it inflects Western episodic narrative models with a distinctly musicalised, Calypsonian mode of storytelling in various registers of creolised English. The narrative is told in third-person mode, by a heterodiegetic narrator using a mix of zero and fixed internal focalisation to offer insight into a large cast of black Londoners, some only recently off the boat, some veterans of the earliest Windrush days, all coping differently with the challenges of the city and adopting different strategies of dealing with its opportunities and depravations over a course of roughly three years. It is this narrator, most of all, who holds the loosely related episodes of the novel together, primarily through a specific quality of voice, a voice which steps out from the page by means of a carefully crafted aurality. The narrator's various registers of creole encompass the voices of all central characters, giving the narration a distinctly collective feel. Still, it is anchored on one primary focalising character whose life and thoughts it is closest to, and who provides the gravitational centre of storytelling: Moses Aloetta, who has been in London longer than any of the other 'boys'. The novel opens with him travelling to Waterloo station to meet a newly arrived fellowTrinidadian:

One grim winter evening, when it had a kind of unrealness about London, with a fog sleeping restlessly over the city and the lights showing in the blur as if is not London at all but some strange place on another planet, Moses Aloetta hop on a number 46 bus at the corner of Chepstow Road and Westbourne Grove to go 
to Waterloo to meet a fellar who was coming from Trinidad on the boat-train. $(23)^{1}$

And it closes with Moses' meditations on the misery and pathos and vastness of black life in the city, all of which he might one day turn into a book:

Daniel was telling him how over in France all kinds of fellars writing books what turning out to be best-sellers. Taxi-driver, porter, road-sweeper - it didn't matter. One day you sweating in the factory and the next day all the newspapers have your name and photo, saying how you are a new literary giant.

He watch a tugboat on the Thames, wondering if he could ever write a book like that, what everybody would buy.

It was a summer night: laughter fell softly: it was the sort of a night that if you wasn't making love to a woman you feel you was the only person in the world like that. (141)

There is, then, a rather close association of the narrator/performer, whose voice identifies him as one of the 'boys' and a veteran migrant who knows all 'ballad', with the figure of Moses. Yet there is no identification in the first person, which would undercut the collective thrust and flow of the narrative, and the plurality of experience it offers to its listeners.

Moses' acquaintances are legion. There is the "fellar name Henry Oliver" (23) he sets out to meet at Waterloo Station, a man he soon nicknames 'Sir Galahad', initially ironically for his heroic naiveté and disarming confusion. Yet Galahad lives up to his name when he eventually conquers both the city and its "crafts" in epic style against all setbacks: "So, cool as a lord, the old Galahad walking out to the road, with plastic raincoat hanging on the arm, and the eyes not missing one sharp craft that pass, bowing his head in a polite 'Good evening' and not giving a blast if they answer or not" (87). There is the Jamaican Tolroy, a friend he happens to meet at the station who sent only for his mother, but finds the extended family hopping off the "boattrain", including his sister Agnes and her husband Lewis. Tolroy's aunt, Tanty, is the only major female West Indian character whose ballad is subsequently shared. She is ridiculed by her family for her ignorance about London ways, but later heroically traverses the city, and in her headstrong manner even convinces the English to adopt Caribbean ways of doing things by pushing a system of buying on credit in the corner shop of her working-class neighbourhood.

Cap(tain) is a Nigerian from a rich family who dropped out of Law School and squandered his money on booze and women. His is the ballad of a black male trickster who survives by his boyish charms which he works on his friends but mostly on white women. He dates an Austrian girl whom he promises to get a night job only to chase more women, steals a watch from an English girl to fund his dates with a German only to end up marrying a French woman, borrowing from his soft-hearted friend Daniel. The tragic-comic climax of Cap's ballad satirising his hyper-masculine

\footnotetext{
${ }^{1}$ Unless otherwise indicated page references in brackets without further designation refer to Selvon 2001.
} 
powers is an episode where he unwittingly picks up a transvestite. Yet even though Moses complains to Galahad that "is fellars like that who muddy the water for a lot of us" (51), "still Moses have compassion for him" (55).

Then there is Bart(holomew), lighter-skinned than the rest of the 'boys', terrified of having to share his very meagre fortunes with them, and trying to pass as Latin American. The narrative takes satirical revenge when he is kicked out of his white girlfriend's house because her daddy "don't want no curly-hair children in the family" (65), and after "a few door slam in Bart face, a few English people give him the old diplomacy, [...] Bart boil down and come like one of the boys" (63). Big City, a Trinidadian with big dreams turns out to be illiterate and in need of Moses to help him "full up" (98) forms after he gets into a car accident. There is Harris, the only one of the 'boys' who has come to riches and socializes with the London upper class, trying to out-English the English wearing bowler hats and parading a copy of The Times wherever he goes. He is embarrassed to the bone when the West Indian mob crashes a party he throws at St. Pancras, especially fearing Five Past Twelve, a weed-smoking Barbadian blacker than midnight" and fond of a rub. Harris is eventually put into place by Tanty, who loudly shatters his mimicking charade: "'Harris!' [...] 'You don't know me? You don't know neighbour who uses to live behind you in George Street? [...] little Harris what used to run about the barrack-yard in shirttail!" (114)

The biting satire of all episodes is counteracted by the warmth and humour of the narrative voice which is, like Moses, ultimately compassionate with all characters, irrespective of their follies and fancies. It is this collectivising voice, too, which counters the isolation and alienation which all characters feel, even if listeners get different degrees of insight into characters' emotions. The tension between isolating introspection and an integrating chorus of collective experiences in The Lonely Londoners is maintained especially through passages of free indirect discourse, mostly reserved for Galahad and, more than anyone else, Moses. Thus, the very heart of the novel around which all ballads and episodes are framed consists of an extended stream-of-consciousness passage using free indirect discourse and no punctuation with Moses as focaliser. Nodding both to modernist literary models and to the solo improvisations of Afro-Caribbean musics, the sequence is framed around a summer night in Hyde Park which triggers an almost unstopping flow of observations, associations, fantasies and memories, most of which revolve around all kinds of sexual encounter. Yet the exuberant flight ends in a blue note, juxtaposing Galahad's youthful rapture with Moses' disillusion of being stuck in a life devoid of movement and meaning:

oh lord Galahad say when the sweetness of summer get in him he say he would never leave the old Brit'n as long as he live and Moses sigh a long sigh like a man who live life and see nothing at all in it and who frighten as the years go by wondering what it is all about. (109-110) 
The profundity of aimlessness, alienation and isolation resonates till the end of the narrative of The Lonely Londoners, "under the kiff-kiff laughter, behind the ballad and the episode" (141). Loss and loneliness are held at bay only by the collective experience of storytelling itself; when "[n]early every Sunday morning, like if they are going to church, the boys liming in Moses room, coming together for a oldtalk" (138), even if that talk only riffs on ever new versions of the same: the dregs of finding work or something to eat, the pleasures of 'coasting lime', of vouching to soon return 'home', but never leaving.

\subsection{Encountering Racism}

It should have come across by now that one of the challenges of The Lonely Londoners is its generic syncretism of various narrative modes, drawing on both English and Caribbean genealogies of telling tales. The novel is, in this sense, also a social realist text, and yet it is not.

The Lonely Londoners astutely observes a city thoroughly segregated by the intersectional lines of class and race. The narrator muses on Tolroy's run-down working class neighbourhood: "London is a place like that. It divide up in little worlds, and you stay in the world you belong to and you don't know anything about what happening in the other ones except what you read in the papers" (74). It acknowledges that within the ghettoised spaces of the city, there is indeed transgression of the barriers of race - Tanty's success in establishing a Caribbean credit system is a case in point, or the local grocer who "from the time spades start to settle in the district, he find out what sort of things they like to eat and he stock up with a lot of things like blackeye peas and red beans and pepper sauce, and tinned breadfruit and ochro and smoke herring" (77). In Rushdie's famous phrase, the West Indian migrants thus locally succeed in "tropicalizing" the city (Rushdie 1988, 354). Selvon reserves productive everyday exchanges between Caribbean and English characters that are largely unburdened by the pathologies of race mainly among the working classes: "It have a kind of communal feeling with the Working Class and the spades, because when you poor things does level out, it don't have much up and down" (75). Yet such solidarities painfully end beyond the boundaries of the "little worlds" of communal exchange.

They end most drastically on the housing and job markets, and the discriminations there are translated into institutional policies on all levels from schools to unions to government institutions. In a revealing incident, Moses explains to Galahad how West Indians are filed at the Labour Exchange:

'Now on all the records of the boys, you will see mark on top in red ink. J-A, Col. That mean you from Jamaica and you black. So that put the clerks in the know right away, you see. Suppose a vacancy come and they want to send a fellar, first they will find out if the firm want coloured fellars before they send you. That save a lot of time and bother, you see.' (46) 
Nick Bentley finds evidence in such passages of how Selvon underscores the perpetuation of everyday racism in the institutions which not only play out precarious black and white Londoners against each other, but more importantly foreclose the possibilities of a joint political movement which could take on matters of systemic racial discrimination. Neither trade unions, nor leftist organisations or the Labour Party really provided a platform and outlet for black politics in the 1950s, and "Black individuals were, therefore, marginalised not only from mainstream white culture, but also from the primary bodies of opposition to dominant power frameworks" (Bentley 2003, 44).

The Lonely Londoners explores the psychological effects of this double marginalisation in bitter-sweet prose passages which break through the "kiff-kiff laughter" (141) of the surface narrative. In a particularly moving episode, Galahad expands on his own "theory about Black" at night, following an episode where a little child shouts "Mummy, look at that black man" (89) in the street, and starts crying when Galahad talks to them:

Galahad would take his hand from under the blanket, as he lay there studying how the night before he was in the lavatory and two white fellars come in and say how these black bastards have the lavatory dirty, and they didn't know that he was there, and when he come out they say hello mate have a cigarette. And Galahad watch the colour of his hand, and talk to it, saying, 'Colour, is you that causing all this, you know. Why the hell you can't be blue, or red or green, if you can't be white? You know is you that cause a lot of misery in the world. Is not me, you know, is you! I ain't do anything to infuriate the people and them, is you! Look at you, you so black and innocent, and this time so you causing misery all over the world!'

So Galahad talking to the colour Black, as if is a person, telling it that is not he who causing botheration in the place, but Black, who is a worthless thing for making trouble all about. (88)

The passage resonates powerfully with Frantz Fanon's furiously poetic analyses of the psychopathologies of race in post-War France and Paris in particular in Peau noire masques blancs, first published in 1952. Black Skin, White Masks only appeared in English in 1967, yet still, the parallels specifically between Fanon's chapter on "The Fact of Blackness" and Galahad's ruminations are difficult to miss. Fanon develops his notion of a bodily 'schema' via describing the habitual act of reaching for and holding a cigarette; he painfully describes how corresponding concepts of self are shattered by the overdetermining scripts of history and race written onto the black skin, and triggered in the moment of white interpellation: "Mama, see the Negro! I'm frightened"; how the "corporeal schema crumbles" under the sheer weight of white "legends, stories, history" of "tom-toms, cannibalism, intellectual deficiency, fetishism, racial defects, slave ships, and above all: 'Sho' good eatin'." And Fanon, too, notes: "One day, [...] I took myself far off from my own presence, far indeed, and made myself an object," relating self to black body "in the third person" (Fanon 2008, 111-112). 
It is tempting on these grounds to interpret the various compensating strategies of the diverse cast of The Lonely Londoners through the lens of Fanon: to pathologise characters like Galahad and Harris who strive to escape the "infernal circle" (Fanon 2008, 116) of racist overdetermination by becoming more English than the English - unlike Tanty, who tries instead to Caribbeanise the motherland; to pathologise characters like Cap or Five Past Twelve, who embrace the racist stereotypes of blackness they encounter, a strategy which Fanon also identifies in the strategic essentialisms of the Negritude movement. And yet, such interpretive moves alone do not do justice to the complexity of the novel which is grounded in the historical realities of London in the 1940s and 1950s and which is, on one level, a realist text. But again, this realism is deliberately challenged by conflicting narrative modes which complicate any straight forward notion of social or psychological verisimilitude.

For not only on the level of story, also on the level of discourse The Lonely Londoners is entangled in the psychopathologies of race. Fanon's (and Galahad's) insights matter, too, that is, in view of complex questions about the larger politics of representation. One of the most difficult questions Sam Selvon would have had to face when conceptualising his novel was not how to draft a realistic image of West Indian life in London during the early Windrush years, including the social and psychological effects of racism. It would have been the question how those depravations should and could be narrated by an (Indo-)Caribbean British writer in an overwhelmingly white literary marketplace, for a potential audience which, too, would have been by and large privileged and white. In a way, then, the dilemma of racist overdetermination which the characters of The Lonely Londoners face is intricately doubled and refracted on the level of storytelling itself. Not unlike Olaudah Equiano before him in the late 1780s, Selvon was confronted with the task of having to assert a black humanity and identity for West Indian migrants in London largely without black literary models, within and against a world of Anglophone letters which still abounded with white "legends, stories, history" of "tom-toms, cannibalism, intellectual deficiency, fetishism, racial defects, slave ships." (Fanon 2008, 111-112) Yet while Equiano attempted everything in his outstanding powers to whitewash stereotypes of blackness - by emplotting his story in a carefully "unvarnished" English (cf. Edwards 1971) and the generic patterns of the spiritual autobiography, and not least by stressing his overachievements in all disciplines of (puritan) civilised life including commerce, austerity and gentlemanly decorum - Selvon in many ways opted for the exact opposite. His is a decolonial assertion of black life in London which flaunts all standards of language, weaves distinctly Caribbean generic patterns into the fabric of storytelling, and which joyfully revels in episodes which confirm the worst nightmares of his potential white bourgeois readers: His 'boys' catch pigeons in the park for dinner; they drink and curse and live on the dole; but worst of all, they conquer the city with their penises. 


\subsection{Sex and the City}

Few other concerns have troubled the critical reception of The Lonely Londoners as much as its take on white women and the seemingly unreflective "propagation of triumphalising forms of black male heterosexual behaviour" (Houlden 2012, 24). At the centre of debates is usually the extended stream-of-consciousness passage at the heart of the novel and its intoxicating flow of loosely related observations, associations and memories induced by a hot summer night in the park, most of which revolve around sex: sex with other precarious Londoners such as ex-junkies (105), prostitutes "from the country districts whom come to see the big life in London" (107) or European domestic workers who "think like the newspapers say about the Jamaicans that the streets of London paved with gold" (103); yet also sex across the barriers of class, as, in the narrator's ironic phrase, "it ain't have no discrimination when it come to that park in the summer" (104). Selvon's focaliser Moses clearly frames those exchanges as more twisted: old white voyeurs, rich women "who want you to live up to the films and stories they hear about black people living primitive" (108), husbands who take a kick out of hustling their wives to black men. Irrespective of the intersectional take on gender and class, however, none of the prostitutes or lovers or girlfriends is given a voice in The Lonely Londoners. They are picked up and dropped, pretty much like objects, and Moses' associated ramblings are full of bravado: "to talk of all the episodes that Moses had with woman in London would take bags of ballad Moses move through all the nationalities in the world and then he start the circle again" (102-103). That swagger, moreover, is clearly directed at the conquest of white woman only, while black women are presented as sexually undesirable: "As far as spades hitting spades it ain't have nothing like that for a spade wouldn't hit a spade when it have so much other talent on parade" (107). This rejection resonates discomfortingly with one of the novel's episodic side-lines, in which Lewis begins to regularly beat up his wife Agnes, Tolroy's sister, suspecting her of infidelity during his long working hours at a job in the city, an episode subsumed within the tragic-comic flow of the overall narrative without much fraction.

The 'slackness' of The Lonely Londoners flies in the face of English contemporary discourses about West Indian migration, by deliberately fuelling, rather than attempting to appease, a moral panic revolving around images of black criminality, sexual licentiousness and fears of miscegenation. As Paul Gilroy remarks: "Concern about the criminal behaviour of black settlers in the late 1940s and 1950s assumed a different form, clustering around a distinct range of anxieties and images in which sexuality and miscegenation were often uppermost" $(1992,79)$. Selvon's take on the intersections of gender and race (and class) has accordingly provoked a range of critical responses and attempts at explanation. 
At its worst, these responses entirely neglect the performative dimension of the text as a whole. A case in point is Lewis MacLeod, who chooses to take the narrative at face value when arguing that "the light-hearted attitude about sex cannot disguise the pathology that underlies it" $(2005,164)$. He draws on critical masculinity studies to propose that in the absence of two crucial attributions of 'real' manhood (according to David Gilmore: man as defender of his "various territories", and man as material provider; cf. Gilmore 1990, 223), the remaining third attribute, that of sexual potency, expands to clinical proportions. In all this, white masculinity "naturalized as a globalized trope" (MacLeod 2005, 164) and exported to the colonies remains the gold standard. Heavily (mis)using Fanon, MacLeod accordingly proposes that the perpetual desire to conquer white women in The Lonely Londoners really only displaces the desire for white masculinity. Sam Selvon's boys are all "mimic men" $(2005,160)$, pathologically trying to screw themselves into the place of the English white male.

While it is possible to take all sorts of issues with this conclusion - a conclusion which apparently conflates the diametrically opposed politics of Selvon and V.S. Naipaul, the more (in)famous and infinitely more anglophile of the two major Indo-Trinidadian writers of the Windrush generation - its major problem is that it ignores the fact that The Lonely Londoners programmatically exceeds ethnographic realism. Sandra Courtman, for instance, remarks how Selvon distinctly satirizes the hyper-masculine exploits of his protagonists, such as when Moses mistakes the orgasmic fits of a girl he picks up in the park and takes home to his "yard" for a fatal paroxysm (2012, 103), while Ashley Dawson (2007) foregrounds how the masculine conquests of white women in The Lonely Londoners remain tied to evocations of isolation, and fail to conquer the pervasive sense of loss. He accordingly posits that beyond the surface realism, there is an implicit critique of the intersections of gendered and colonial hegemonies:

The Lonely Londoners also stresses the hollow character of the sexual adventurism of 'the boys,' suggesting that their triumphs in the bedroom fail to create truly egalitarian and postimperial relations among the novel's characters. Instead of dismantling colonial power relations, that is, the boys' conquests simply invert those relations through the creation of gender hierarchy. (2007, 36)

Yet beyond such degrees of authorial reflexivity, it is vital not to take the larger narrative at face value in a more encompassing approach that attends to it creole orality: to take account of the fact that, as John Thieme has elaborated, The Lonely Londoners is a "carnival text in that it subverts the norms of the dominant tradition of Western fiction by instating the oral over the literary" $(2003,62)$. The inversion of colonial power relations which Dawson talks about and which is intricately played out, among other fields, in the performance of gender relations is thus part of a larger generic strategy, a decolonial strategy deeply rooted in the "carnival mentality in Trinidad" which as long as it is "a genuine expression of the culture of the 
marketplace [...] provides through parody, subversion and irony a source of renewal" (Thieme 2003, 62).

One of the most profound interventions into the debates of gender and race in The Lonely Londoners building on this insight is Kate Houlden's (2012), who argues that the novel's often noted recourse to calypsonian models matters not only as an aesthetic structuring device, but is also foundational for its racial and sexual politics. Following Simon Gikandi's seminal insight that popular cultural styles of performance like calypso are "important because they challenge the very foundations of Eurocentric cultural codes and suggest and alternative hermeneutics" (1992, 96), Houlden traces the parallels between the narrative performance of the novel and performances of hyperbolic black masculinity in calypso, a form of expression originating in the creole experience of slavery and the profanating subversion and mimicry of the white masters' discourse. Drawing on the Mighty Sparrow's controversial song "Congo Man" as an example, in which Sparrow sings about white women being attacked and eaten by African men (riffing on contemporary reports of the Belgian Congo), she traces how the calypsonian deliberately expropriates white fantasies of black savagery, using hyperbolic laughter and inversion as a satirical weapon to confront and to dismantle limiting stereotypes of blackness (cf. Houlden 2008, 34-35). There is, in this sense, a profound potential for decolonial selfassertion and renewal in the carnivalesque irony pervading The Lonely Londoners, modelled on a mode of performance which would not have been alien to contemporary English audiences either, as Calypso had long travelled beyond Trinidad, most notably in the person of the Mighty Sparrow's arch-rival Lord Kitchener on the very MV Windrush in 1948. Yet of course, it also comes at a certain cost: This may less be Western readers on whom the Caribbean generic dimensions of performance are lost and who see their prejudices confirmed in seeming social and psychological realisms. It rather concerns the detrimental side effects of "a real carnival slackness" (99) on the politics of representing black women against Eurocentric stereotypes, within a West Indian 'alternative hermeneutics' that is translated into the Western form of the novel.

\subsection{City Tactics and New Communities}

The most profound effect of Sam Selvon's creolised and carnivalising narrative, however, is its forging of a transnational migrant community across markers of difference, and the inscription of this community into the fabric of London. The Lonely Londoners performatively redraws the map of the city, and claims it as a West Indian metropolis by way of its narrative manoeuvres. This concerns particularly the use of language and naming by the narrator and characters, as well as their various movements and everyday practices. 
Rebecca Dyer (2002) lucidly explores how Selvon's characters turn from what Michel de Certeau labels as the "consumers" or "dominated element in society" $(1988,475)$ into creative agents actively shaping the city by their everyday moves. Still in the Caribbean, they were indeed 'consumers' of an ideal image of Englishness, taught to them in school curricula, in English literatures and the imperial media, imbuing London's landmarks - Waterloo Station, Piccadilly Circus, Marbel Arch, Hyde Park - with a mythical fantasy structure marketed as imperial home. Yet when confronted with the everyday racist disavowal of their claim on the markers of Englishness and home alike when they reach London, in a society which strives to delete their visibility from the cityscape precisely for the visibility of their skin in all official walks of life - as Susheila Nasta puts it: "the black man was the backbone of the city, but he was only seen at night" $(2002,79)$, working in the back of restaurants, behind the railway station - the lonely Londoners draw on different tactics which creatively poach on the available scripts of dominant society. In Dyer's words, their "'poaching' can be seen as their simultaneous borrowing, critique, and transformation of the metropolitan culture - their reworking of the very language, literary genres, and way of life that had been valorized during their colonial schooling". They thus become involved in the "poiesis of their urban surroundings" (Dyer 2002, 109-110), they bring forth, in their wanderings, actions and linguistic practices, a new London which they depropriate as a new home, refracting and defamiliarising older colonial representations of the city.

It is important not to read the decolonial tactics of The Lonely Londoners in an exclusively celebratory tone, and thus to elide the social critique of the novel's poetic assertion of a West Indian London. Lisa Kabesh follows Dyer in confirming that "The Lonely Londoners is an enunciative text; it produces the community it describes in the act of writing, recording and mapping its voices and movements" $(2011,4)$; yet she also draws attention to the fact that the novel recurrently charts "sites of racist exclusion", and thus presents "a detailed topography of racial hierarchy in the metropole" $(2011,4)$. Yet even if the characters' movements are limited, they powerfully reconfigure the London they find. This already begins in the opening episode, on Moses' bus ride from Bayswater to Waterloo, reconfigured in Moses' nostalgic memories and associations of Caribbean arrivals and departures from an inner city railway terminal and tube station named after one of the key events in European history into the central bridge head connecting London with the West Indies. Much of the movement in the novel is then set between the (then) run-down migrant neighbourhood of Notting Hill and the posh city centre, roughly between Notting Hill Gate, Hyde Park and Marble Arch all the way to Mayfair and Soho, as when Galahad walks from Bayswater Road to Piccadilly Circus to meet his date Daisy; as in Cap and Moses' regular summer nights 'coasting lime' on Bayswater Road; or around Speakers Corner which is "a regular for the boys" on Sunday 
evenings, listening "to them fellars talking about how the government this and that, or making big discussion on the colour problem" (98).

The choice of familiar tourist landmarks to chart the "boys" movements is deliberate, and their West Indian depropriation is geared by a subtle politics of language and naming, the importance of which for "decolonising the mind" (wa Thiong'o 1986) has become a standard trope in postcolonial studies only about three decades after Selvon's literary interventions. Inverting the colonial appropriation of the Caribbean by the power of naming (the literary master trope still is Crusoe's naming of 'Friday'), initiation into the group of migrant Londoners comes with a creole register of place names, from the Circus to the Arch to the Gate, mapping an archipelagic logic onto the city:

'Which part you living?' Galahad say.

'In the Water. Bayswater to you until you living in the city for at least two years.'

'Why they call it Bayswater? Is a bay? It have water?'

'Take it easy,' Moses say. 'You can't learn everything the first day you land. [...]' (35-36)

By extension, it is primarily the creole continuum represented by the kaleidoscope of voices in the novel, including that of the storyteller, which carves out a space of belonging for the lonely Londoners against the dominant scripts of whiteness and Englishness in the city. "What wrong with it? [...] Is English we speaking", Galahad answers Daisy when having Caribbean-style tea in his yard and she confesses that she struggles with "[t]he way you West Indians speak" (93). It is in this self-assured assertion of being and becoming through language that the community of The Lonely Londoners belongs - not in the poststructuralist sense of linguistic constructivism, but in the sense of a creolised language which productively negotiates and sets into motion two distinct 'hermeneutics' or epistemologies; a language which firmly stakes its claims on Englishness, yet an Englishness defamiliarised and inflected by diverse oral registers of the Caribbean. Sam Selvon's community of lonely Londoners, albeit distinctly gendered, holds beyond the need for identification with bounded entities such as nation, class, ethnicity, religion or political conviction, not entirely unlike Esposito's notion of a Communitas not based on joint 'property' but rather the shared lack of it, or Agamben's Coming Community. The community of The Lonely Londoners is partly framed in the negative, by the collective experience of racist exclusion from the "good life" of social and political participation; yet it is in the collective performance of "a oldtalk" in Moses' room each Sunday morning, "with London and life on the outside" (140), that it breathes life.

\section{Aesthetics: Narrative and Literary Strategies}

As the previous chapters have shown, the 'topics and concerns' of The Lonely Londoners cannot be discussed independently of the novel's 'narrative and literary 
strategies'. The most important elements have already been expanded upon: the episodic structure drawing on modernist models as much as on Caribbean oral and musical forms; a heterodiegetic narrator/performer who nevertheless closely partakes in the story-world by means of an 'aural' quality of narrative voice which encompasses the diverse registers of creole spoken by the characters, and which gives the narrative a distinctly collective feel; the frequent recourse to free indirect discourse and, at the heart of the novel, the extended use of stream of consciousness technique to allow for introspection within the collective thrust of the overall narrative. The innovation of all this was not lost on Selvon himself, who claimed in an interview: "I think I can say without a trace of modesty that I was the first Caribbean writer to explore and employ dialect in a full-length novel where it was used in both narrative and dialogue. I was boldfaced enough to write a complete chapter in a stream-of-consciousness style" (Selvon qtd. in Fabre 1988, 69). While the credit for the first novel in what was then called Caribbean 'dialect' might have to go to V.S. Reid's New Day (1949), the uniqueness of The Lonely Londoners lies indeed in its "boldface" combination of high modernist as well as realist literary models with Caribbean styles and modes of narrative worldmaking, transported by a carefully crafted literary creole, and the performative humour, swagger and satirical edge of Trinidadian popular styles such as calypso.

The creolité of Sam Selvon's approach was only much later, and especially in francophone Caribbean discourses, theorised as a powerful tool of decolonial literary self-assertion, a tool which, in Walter Mignolo's (2000) terms, allows to negotiate "local histories" and "global designs" of storytelling in productive, interepistemic dialogue. In their In Praise of Creoleness, Patrick Camoiseau, Raphaël Confiant and Jean Bernabé lay out a literary programme which could be modelled on The Lonely Londoners, by asserting the continuing relevance of oral epistemologies in the modern world system: "In short, we shall create a literature", they write, "which will obey all the demands of modern writing while taking roots in the traditional configurations of our orality" $(1993,98)$.

It is remarkable in this context that Selvon did not originally intend a novel entirely in creole. He comments on the genesis of the novel:

I had difficulty starting the novel in straight English. The people I wanted to describe were entertaining people indeed, but I could not really move. At that stage, I had written the narrative in English and most of the dialogues in dialect. Then I started both narrative and dialogue in dialect and the novel just shot along. (Selvon qtd. in Fabre 1988, 66)

The reason why the novel would have "shot along" in this new approach is that it no longer allowed for what Catherine Belsey terms a "hierarchy of discourses" that is typical of the "illusionism" of realist fiction, featuring an authorial voice which establishes and vouches for "the truth of the story" $(1980,70)$. To install a narrator/performer speaking the same literary creole as his characters was thus 
much more than merely an aesthetic move: It was also a key ideological move which challenges dominant philosophies of subjectivity, both in the trajectory of the English novel, and in the cultures of modernity at large. In Belsey's terms again, "the subject finds in the discourse of the classic realist text a confirmation of the position of autonomous subjectivity represented in ideology as 'obvious", and it is this naturalisation of bounded subjectivity which Selvon's move shatters: "It is possible to refuse that position", notes Belsey, "but to do so, at least at present, is to make a deliberate and ideological choice" $(1980,70)$. The narrative subject in The Lonely Londoners undercuts the notion of monadic subjectivity installed by the bourgeois interventions of the European Enlightenment whose universalist projections of a common humanity were from its inception flawed by an endemic racism (cf. James 1989). Instead, the authorial self is inherently relational and collective, extending into and blending with the performed voices of characters, refraining from judgement or a drive toward closure. As Gordon Rohlehr, the doyen of calypso criticism, writes: "In The Lonely Londoners it is the group that has a full self, that faces the wilderness and survives" $(1988,41)$.

It is vital to note in this context that Selvon's approach to narrative voice does not simply displace the liberalist traditions of European authorial narration by a purportedly 'authentic' Caribbean orality. Selvon is outspoken about the fact that his discourse is, in the best sense, "artificial and fabricated". He remarks:

I did not pick the Jamaican way of talking in London. I only tried to produce what I believed was thought of as a Caribbean dialect. The modified version in which I write my dialect may be a manner of extending the language. It may be called artificial and fabricated. The way I treat the language is not the way it is spoken in Jamaica, or Barbados, or Trinidad either, for that matter. I only resorted to a modified Trinidadian dialect because, much more than Jamaican or Barbadian English, it is close to 'correct Standard English', and I thought it would be more recognizable to the European reader. (Selvon qtd. in Fabre 1988, 67)

Selvon's policy of "extending the language" for his literary purposes shuns simplistic notions of tradition or authenticity played out against trajectories of the modern. Rather, it is inclusive in its approach to creolité, along the lines outlined by Camoiseau, Confiant and Bernabé: It is inclusive in the more profane sense of catering to a plural range of readerships, be they European, West Indian or situated elsewhere. Yet in a more profound sense it is inclusive in not rejecting, but adopting and syncretising Western literary traditions within the alternative epistemologies of West Indian styles. Kathy Birat (2009) puts this most elegantly when she insists that Selvon was not simply dumbing down creole Englishes for Western readers, but that he was instead "increasing the capacity of the language to become a dimension of the narrative, to express more than just a Caribbean reality". Selvon, she holds, "was ultimately creating what Bakhtin would call an 'image' of the language, thus bringing it into dialogic tension with the other languages of the English novel. This was Selvon's stroke of genius" $(2009,3)$. 
The Lonely Londoners does not subvert, or write back in anger to the English novel, the more recent histories of which are unfolded in this handbook. Rather, it generously endows an ossified tradition with new aesthetic and ideological possibilities. Most fundamentally, it explores ways of writing beyond the endemic loneliness not only of its characters, but of the modern (literary) condition. Distinctly geared against what Michael Taussig frames as a "self-enclosed and somewhat paranoid, possessive, individualized sense of self [...] within a system wherein that self ideally incorporates [...] wealth, property, citizenship" (1993, 97), the novel programmatically draws on what Paul Gilroy called the "ethics of antiphony" inherent in Black Atlantic epistemologies, an ethics that is deeply rooted in "the experience of performance with which to focus the pivotal relationship between performer and crowd, participant and community" (1993, 203). The Lonely Londoners is in this sense a novel that is not only to be read, but also to be carefully listened to, as its ballads call for a communal response. That response is triggered, first and foremost, by the artful musicalisation and seemingly effortless flow of language. Selvon himself emphasises that he spent hours on perfecting the sound of his writing: "I experimented with the language as it is used by Caribbean people. I found a chord, it was like music, and I sat like a passenger in a bus and let the language do the writing" (Selvon 1995, 60). The result is a text which translates the Trinidadian carnival tent onto the readerly page; a text which models its collectivising authorial voice on the figure of the calypsonian and his "fierce commitment to the life of the reveller, the man who has not yet been sophisticated into shame and respectability" (Rohlehr qtd. in Houlden 2012, 33), an 'aural' text which sustains the tragic-comic spirit of the calypsonian ballad with all its "subversive irony, the melodramatic exaggeration of farcical anecdotes, racial stereotyping, repetition for dramatic effect and the inclusion of topical political material" (Nasta 2002, 57) in a carnivalesque performance which ultimately explodes the petty boundaries of race, class and nation.

\section{Reception and Theoretical Perspectives}

The critical reception of The Lonely Londoners initially missed out on the elaborate craft and conceptual complexity behind Selvon's sonic experiments. It had been strongly affected by a passage in George Lamming's The Pleasures of Exile, published in 1960, in which he sides with Selvon as a 'folk' writer representative of a "peasant sensibility" against the likes of V. S. Naipaul, who "with the diabolic help of Oxford University, has done a thorough job of wiping this out of his guts" (Lamming 1960, 225). Lamming highlights Selvon's humour, pathos and decolonial politics in a perspective which foregrounds all the calypsonian qualities just mentioned - yet he does so by diametrically opposing them to 'English' writing: 
Writers like Selvon and Vic Reid - key novelists for understanding the literary and social situation in the West Indies - are essentially peasant. That's a great difference between the West Indian novelist and his contemporary in England. For peasants simply don't see like middle-class people. The peasant tongue has its own rhythms which are Selvon's and Reid's rhythms; and no artifice of technique, no sophisticated gimmicks leading to the mutilation of form, can achieve the specific taste and sound of Selvon's prose. $(1960,45)$

There are all sorts of issues with this statement, as Susheila Nasta points out: Selvon was himself middle-class, and wrote in a variety of styles; his language and rhythms are hardly the product of an unsophisticated immediacy, but "the result of a conscious and sophisticated craft" $(1988,8)$. And surely, his most outstanding performance in The Lonely Londoners is the syncretistic incorporation of realist and modernist techniques into the antiphonic ethics of Caribbean orality. Still, the label of 'peasant writer' stuck. Barrie Davis reiterated in 1972 that Selvon's rendition of the West Indian migrant experience is "peripheral to any complexity or subtlety" (1972, 67), while Frank Birbalsingh, otherwise an astute observer of West Indian literature, noted in 1977 that Selvon's "dominant subject remains a plain, comic representation of West Indian manners" (1977, 15). A more profound revision of Lamming's "romantic oversimplification" (MacDonald 1979, 203) really only set in in the 1980s, which saw the first book-length collection of criticism on Selvon's work, edited and compiled by Susheila Nasta in 1988. It is here, as well as in more recent criticism much of which has informed this chapter, that The Lonely Londoners begins to trigger productive controversies on the politics of race, class and gender, syncretistic narrative strategies and interepistemic challenges. Given its amazing potential for postcolonial thought, however, the overall critical attention to the novel has remained comparatively sparse. David Dabydeen once claimed that "Selvon was so ahead of his time that [...] the critics [...] didn't know what he was doing" (Dabydeen qtd. in Ingrams 2001, 34). That may still be true to some extent, and it may include this essay. 60 years after its first publication, in an ever more dramatically unequal world in which more human beings than ever before seek better lives elsewhere, it is vital to eventually catch up with the profound vision of The Lonely Londoners; with its humanity and compassion, with its intimation of community beyond the confines of the (neo)colonial and (neo)liberal alike, and not least with its calypsonian critique of limiting Eurocentric worldings.

\section{Bibliography}

\subsection{Works Cited}

Selvon, Sam. The Lonely Londoners. New York: Longman, 2001 [1956]. 
Agamben, Giorgio. The Coming Community. Minneapolis: University of Minnesota Press, 1993.

Belsey, Catherine. Critical Practice. London: Routledge, 1980.

Bentley, Nick. "Black London: The Politics of Representation in Sam Selvon's The Lonely Londoners." Wasafiri 39 (2003): 41-45.

Bentley, Nick. "Form and Language in Sam Selvon's The Lonely Londoners." ARIEL 36.3 (2005): 67-84.

Bernabé, Jean, Patrick Chamoiseau, and Raphael Confiant. In Praise of Creoleness. Trans. M.B. Taleb-Khyar. Paris: Gallimard, 1993.

Birat, Kathie. "Seeking Sam Selvon: Michel Fabre and the Fiction of the Caribbean." Transatlantica 1.1 (2009): 2-9.

Birbalsingh, Frank. "Samuel Selvon and the West Indian Literary Renaissance." ARIEL 8.3 (1977): 5-22.

Burton, Jonathan, and Ania Loomba, eds. Race in Early Modern England: A Documentary Companion. New York: Palgrave, 2007.

Courtman, Sandra. "Women Writers and the Windrush Generation: A Contextual Reading of Beryl Gilroy's In Praise of Love and Children and Andrea Levy's Small Island." EnterText 9 (2012): 84-104.

Davies, Barrie. "A Sense of Abroad: Aspects of the West Indian Novel in England." World Literature Written In English 2.2 (1972): 67-80.

Dawson, Ashley. Mongrel Nation: Diasporic Culture and the Making of Postcolonial Britain. Michigan: University of Michigan Press, 2007.

De Certeau, Michel. The Practice of Everyday Life. Trans. Steven Rendall. Berkeley: University of California Press, 1988 [1984].

Dyer, Rebecca. "Immigration, Postwar London, and the Politics of Everyday Life in Sam Selvon's Fiction." Cultural Critique 52.1 (2002): 108-144.

Edwards, Paul. "Equiano's Round Unvarnished Tale." African Literature Today 5 (1971): 12-20.

Esposito, Roberto. Communitas: The Origin and Destiny of Community. Stanford, CA: Stanford University Press, 2010.

Fabre, Michel, "Samuel Selvon: Interviews and Conversations." Critical Perspectives on Sam Selvon. Ed. Susheila Nasta. Washington: Three Continents Press, 1988. 64-76.

Fanon, Frantz. Black Skin, White Masks. Trans. Richard Philcox. New York: Grove Press, 2008 [1952].

Fryer, Peter. Staying Power: The History of Black People in Britain. London: Pluto, 1987.

Gikandi, Simon. Writing in Limbo: Modernism and Caribbean Literature. Ithaca, NY and London: Cornell University Press, 1992.

Gilmore, David. Manhood in the Making: Cultural Concepts of Masculinity. New Haven: Yale UP, 1990. 
Gilroy, Paul, The Black Atlantic: Modernity and Double Consciousness. London: Verso, 1993.

Gilroy, Paul. There Ain't No Black in the Union Jack: The Cultural Politics of Race and Nation. London: Routledge, 1992.

Gramaglia, Letizia, and Malachi Mclntosh. "Censorship, Selvon and Caribbean Voices: 'Behind the Humming Bird' and the Caribbean Literary Field." Wasafiri 28.2 (2013): 48-54.

Houlden, Kate. "Sam Selvon's The Lonely Londoners (1956), White Sexual Desire and the Calypso Aesthetic." Journal of West Indian Literature 20.2 (2012): 2437.

Ingrams, Elizabeth. "The Lonely Londoners: Sam Selvon and the Literary Heritage." Wasafiri 33 (2001): 33-41.

James, C. L. R. The Black Jacobins: Toussaint L'Ouverture and the San Domingo Revolution. London: Vintage, 1989.

Kabesh, Lisa. "Mapping Freedom, or Its Limits: The Politics of Movement in Sam Selvon's The Lonely Londoners." Postcolonial Text 6.3 (2011): 1-17.

Lamming, George. The Pleasures of Exile. London: Michael Joseph, 1960.

Looker, Mark. Atlantic Passages: History, Community and Language in the Fiction of Sam Selvon. New York: Peter Lang, 1996.

MacDonald, Bruce F. "Language and Consciousness in Samuel Selvon's A Brighter Sun." English Studies in Canada 5 (1979): 202-215.

MacLeod, Lewis. "You Have to Start Thinking All Over Again': Masculinities, Narratology and New Approaches to Sam Selvon." ARIEL 36.1-2 (2005): 157181.

Mignolo, Walter D. Local Histories/Global Designs: Coloniality, Subaltern Knowledges, and Border Thinking. Princeton, NJ: Princeton University Press, 2000.

Nasta, Susheila. "Introduction." Critical Perspectives on Sam Selvon. Ed. Susheila Nasta. Washington, DC: Three Continents Press, 1988. 1-14.

Nasta, Susheila. Home Truths: Fictions of the South Asian Diaspora in Britain. Basingstoke: Palgrave, 2002.

Nasta, Susheila, and Anna Rutherford, eds. Tiger's Triumph: Celebrating Sam Selvon. Armidale, New South Wales: Dangaroo Press, 1995.

Ramchand, Kenneth. "Introduction." The Lonely Londoners. New York: Longman, 2001. 3-21.

Rohlehr, F. Gordon. "The Folk in Caribbean Literature." Critical Perspectives on Sam Selvon. Ed. Susheila Nasta. Washington, DC: Three Continents Press, 1988. 29-43.

Rushdie, Salman. The Satanic Verses. New York: Viking, 1988. 
Selvon, Sam. "Finding West Indian Identity in London." Tiger's Triumph: Celebrating Sam Selvon. Eds. Susheila Nasta and Anna Rutherford. Arimdale, New South Wales: Dangaroo Press, 1995. 58-61.

Taussig, Michael. Mimesis and Alterity: A Particular History of the Senses. New York: Routledge, 1993.

Thieme, John. "The World Turn Upside Down: Carnival Patterns in The Lonely Londoners." Something Rich and Strange: Selected Essays on Sam Selvon. Ed. Martin Zehnder. Leeds: Peepal Tree, 2003. 51-64.

wa Thiong'o, Ngugi. Decolonising the Mind: The Politics of Language in African Literature. London: Heinemann Educational, 1986.

Winder, Robert. Bloody Foreigners: The Story of Immigration to Britain. London: Little, Brown, 2004.

\subsection{Further Reading}

Looker, Mark. Atlantic Passages: History, Community and Language in the Fiction of Sam Selvon. New York: Peter Lang, 1996.

Nasta, Susheila, and Anna Rutherford, eds. Tiger's Triumph: Celebrating Sam Selvon. Armidale, NSW: Dangaroo Press, 1995.

Nasta, Susheila, ed. Critical Perspectives on Sam Selvon. Washington DC: Three Continents Press, 1988.

Zehnder, Martin, ed. Something Rich and Strange: Selected Essays on Sam Selvon. Leeds: Peepal Tree, 2003. 